Original Research Paper

\title{
Structural Dynamics of the Distribution Mechanism with Rocking Tappet with Roll
}

\author{
${ }^{1}$ Florian Ion T. Petrescu, ${ }^{2}$ John Kaiser Calautit, and ${ }^{3}$ Dragan Marinkovic \\ ${ }^{I}$ Department of Theory of Mechanisms and Robots, Bucharest Polytechnic University, Bucharest, Romania \\ ${ }^{2}$ Department of Mechanical Engineering, University of Sheffield, Sheffield, UK \\ ${ }^{3}$ Department of Structural Analysis, Berlin Institute of Technology, Berlin, Germany
}

Article history

Received: 18-9-2015

Revised: $14-10-2015$

Accepted: 16-10-2015

Corresponding Author:

Florian Ion T. Petrescu

Department of Theory of

Mechanisms and Robots, Bucharest

Polytechnic University, Bucharest,

Romania

Email: scipub02@gmail.com

\begin{abstract}
In this study, the authors present a new method to dynamically synthesize a mechanism with rotary cam and rotated tappet with roll, used with priority at the distribution mechanisms from the heat engines with internal combustion. This type of distribution can improve the changes of gases and may decrease significantly the level of vibration, noises and emissions. As long as we produce electricity and heat by burning fossil fuels it is pointless to try to replace all thermal engines with electric motors, as the loss of energy and pollution will be even larger. However, thermal engines should be continuously improved to reduce fuel consumption. A great loss of power is attributed to heat engines with internal combustion and distribution mechanism, a reason for the improvement of the functionality of this mechanism. The dynamic synthesis of this type of distribution mechanism can be made shortly, by the Cartesian coordinates, but to determine these coordinates we need trigonometric parameters of the mechanism. Dynamics and forces of this distribution mechanism are presented as well. One introduces the dynamic coefficient D.
\end{abstract}

Keywords: Distribution Mechanism, Rotary Cam, Rotating Tappet With Roll, Cam Dynamics, Cam Dynamic Synthesis, Forces, Velocities, Powers, Efficiency, Dynamic Coefficient

\section{Introduction}

Distribution mechanisms with rotary cam and rotated tappet with roller have a unique kinematic due primarily to the mechanism of geometry, which forces experts to study them in greater detail to determine the kinematic and dynamic precision of these mechanisms.

Typically the study of this type of mechanism is made by approximation, considering being enough for both, kinematic and dynamic to study the center of the coupling B (the center of the roll). This approximation has a great weakness, because it neglects dynamic kinematics, the forces transmission and precision of the mechanism, which leads to a dynamic study inadequate.

In this study the authors present shortly an original trigonometric method to make the dynamic synthesis of a mechanism with rotary cam and rotated tappet with roll, used with priority at the distribution mechanisms from the heat engines with internal combustion (Amoresano et al., 2013; Anderson et al., 1984; Angelas and Lopez-Cajun, 1988; Antonescu et al., 2000; 1987; Barzegari, 2011; Bishop, 1950; Choi and Kim, 1994; De Falco et al., 2013a; 2013b; Ganapathi and Robinson, 2013; Giordana et al., 1979; Hain, 1971; Heywood, 1988; Hrones, 1948; Karikalan et al., 2013; Leidel, 1997; Mahalingam and Ramesh Bapu, 2013; Naima and Liazid, 2013; Narasiman et al., 2013; Petrescu and Petrescu, 1995; 2005a; 2005b; Petrescu et al., 2005; Petrescu, 2008; Petrescu and Petrescu, 2014; 2013a; 2013b; 2011; Petrescu, 2012a; 2012b; Petrescu and Petrescu, 2013c; 2013d; Rahmani et al., 2013; Ravi and Subramanian, 2013; Ronney et al., 1994; Samim and $\mathrm{Tu} \square$ mer, 1993; Sapate and Tikekar, 2013; Sethusundaram et al., 2013; Shriram, 2012; Taraza, 2002; Wang, 2011; Xianying, 2011; Zahari et al., 2013; Zhao et al., 2012). 
This type of distribution can improve the changes of gases and may decrease significantly the level of vibration, noises and emissions.

As long as one produces electricity and heat by burning fossil fuels is pointless to try to replace all thermal engines with electric motors, as loss of energy and pollution will be even larger. However, it is well to continuously improve the thermal engines, to reduce thus fuel consumption (Petrescu, 2015b).

At the heat engine with internal combustion a great loss of power is realized and by the distribution mechanism and for that reason must try to improve the functionality of this mechanism.

The synthesis of this type of distribution mechanism can be made shortly, by the Cartesian coordinates, but to determine these coordinates it need trigonometric parameters of the mechanism.

Why must experts study today this type of mechanism? The first human revolution was produced by the mechanisms with cams used in the automatic looms introduced in England in 1719 by John Kay. The second human revolution was produced in 1866 when the German engineer Nikolaus August Otto has invented his engine with gas, a heat engine with internal combustion with distribution having all valves in the known today form of mushrooms. Cam mechanisms can transmit high forces and loads with a high reliability and dynamic. For this reason they are irreplaceable in various fields in which they are used. Distribution mechanisms with cam, follower and valve are irreplaceable in internal combustion engines.

The structural synthesis of these types of distribution mechanisms can be made shortly by the Cartesian coordinates, but to determine these coordinates need and some trigonometric parameters of the mechanisms.

\section{Forces, Velocities, Powers, Efficiency of Mechanism}

In this study, we propose to study the dynamics of the distribution mechanism module $F$, with rotation cam and rotating tappet with roll (Fig. 1). This type of distribution mechanism is more reliable and has a better dynamic in work. It can work at higher rotational speed with a better efficiency.

Speeds and forces transmitted by the mechanism can be realized in the Fig. 2 .

We can write these forces and speeds (relations of the system 1):

$$
\begin{aligned}
& \left\{\begin{array} { l } 
{ \{ \begin{array} { l } 
{ F _ { a } = F _ { m } \cdot \operatorname { s i n } \alpha } \\
{ v _ { a } = v _ { m } \cdot \operatorname { s i n } \alpha }
\end{array} \quad \{ \begin{array} { l } 
{ F _ { n } = F _ { m } \cdot \operatorname { c o s } \alpha } \\
{ v _ { n } = v _ { m } \cdot \operatorname { c o s } \alpha }
\end{array} }
\end{array} \left\{\begin{array}{l}
F_{c}=F_{n} \cdot \sin \delta \\
v_{c}=v_{n} \cdot \sin \delta
\end{array}\right.\right. \\
& \left\{\begin{array}{l}
F_{u}=F_{n} \cdot \cos \delta=F_{m} \cdot \cos \alpha \cdot \cos \delta \\
v_{u}=v_{n} \cdot \cos \delta=v_{m} \cdot \cos \alpha \cdot \cos \delta
\end{array}\right. \\
& \left\{\begin{array}{l}
P_{u}=F_{u} \cdot v_{2}=F_{m} \cdot v_{m} \cdot \cos ^{2} \alpha \cdot \cos ^{2} \delta \\
P_{c}=F_{m} \cdot v_{m}
\end{array}\right.
\end{aligned}
$$

where, $F_{M}$ and $v_{m}$ mean the force of entry (input force) and entry velocity (input velocity); both perpendicular to $\mathrm{OA}$ in $\mathrm{A}$ (green color on the Fig. 2).

Force $F_{m}$ can be broken down into two components: $F_{a}$ (blue) and $F_{n}$ (red); (The velocity $V_{m}$ as well).

Component $F_{a}$ is a force to slip between elements tangential to the two profiles contact in point $\mathrm{A}$, it produces slippage between the two profiles (the cam and roller tappet). This component gives a moment to roll center B $\left(M=F_{a} . r_{b}\right)$, moment which can produce the rolling of roll (This is advantageous because it always changes the focal point of the roll, which is thus reduced wear and uniformity throughout the surface of the roller).

Component $F_{n}$ is the main one, which is transmitted to the roller and then to the tappet. It is perpendicular to $F_{a}$ and tangent to the right n-n passing through the points $A$ and $B$. When the follower rises (as shown in Fig. 2) force $F_{n}$ presses the roller, so it is directed from A to B.

Force $F_{n}$ (red) shall be forwarded radial to the center roll where it can be broken down into two components, in two directions: one direction is along tappet from B to $\mathrm{D}$ and the other direction is perpendicular on the pushrod (DB) in B.

Component $F_{c}$ (mustard color) presses the follower along it, thus compressing it and component $F_{u}$ (mauve color) perpendicular in $\mathrm{B}$ on $\mathrm{DB}$, produces tappet rotation around tappet pivot $D$, as it is up to the single part useful. All speeds decompose like forces. Relations linking forces and those of speeds are given in the system (1). As can be seen, there are two angles of pressure, $\alpha$ and $\delta$. Instantaneous yield mechanism (see the relationship 2), is the ratio between utile (output) power and consumption (input) power, so using the last two relations of the system (1) obtain the expression instantly the mechanical efficiency of the mechanism (2):

$$
\left\{\begin{array}{l}
\cos \alpha \cdot \cos \delta=\frac{\psi^{\prime} \cdot b}{r_{A}} \cdot \cos ^{2} \delta \\
\eta_{i}=\frac{P_{u}}{P_{c}}=\cos ^{2} \alpha \cdot \cos ^{2} \delta= \\
=(\cos \alpha \cdot \cos \delta)^{2}=\left(\frac{\psi^{\prime} \cdot b}{r_{A}} \cdot \cos ^{2} \delta\right)^{2}= \\
=\frac{\psi^{\prime 2} \cdot b^{2}}{r_{A}^{2}} \cdot \cos ^{4} \delta \\
\eta_{i}=\frac{P_{u}}{P_{c}}=\cos { }^{2} \alpha \cdot \cos ^{2} \delta= \\
=(\cos \alpha \cdot \cos \delta)^{2}=\frac{\psi^{\prime 2} \cdot b^{2}}{r_{A}^{2}} \cdot \cos ^{4} \delta
\end{array}\right.
$$




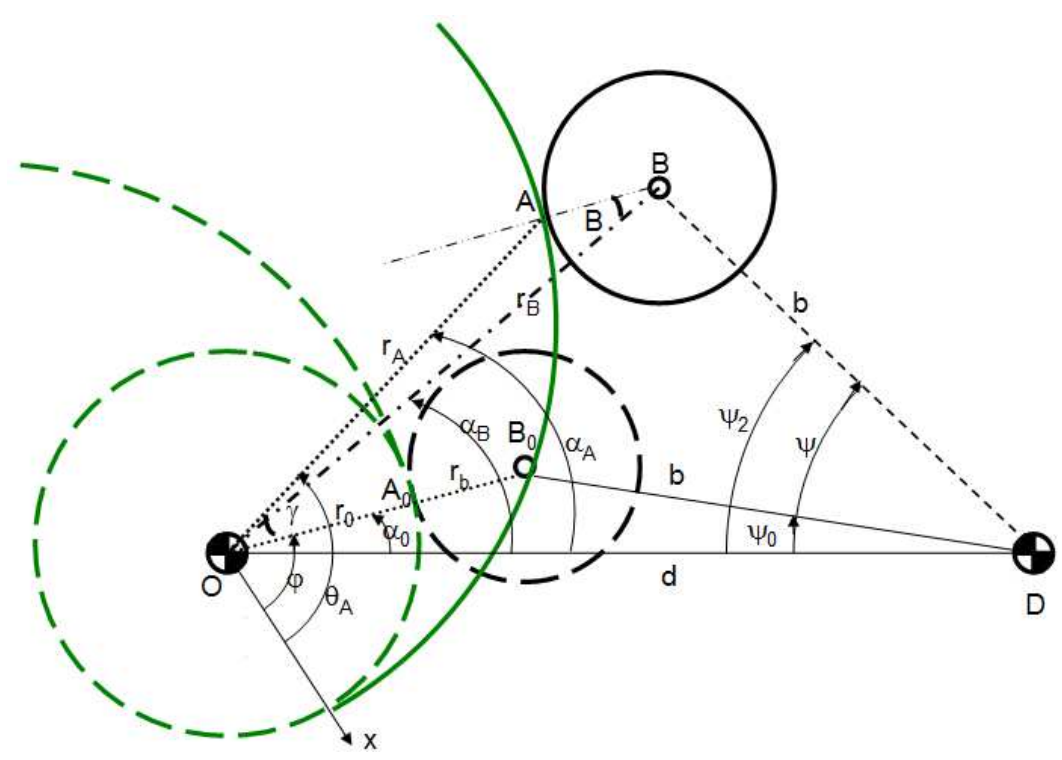

Fig. 1. Mechanism with rotating cam and rotating tappet with roll

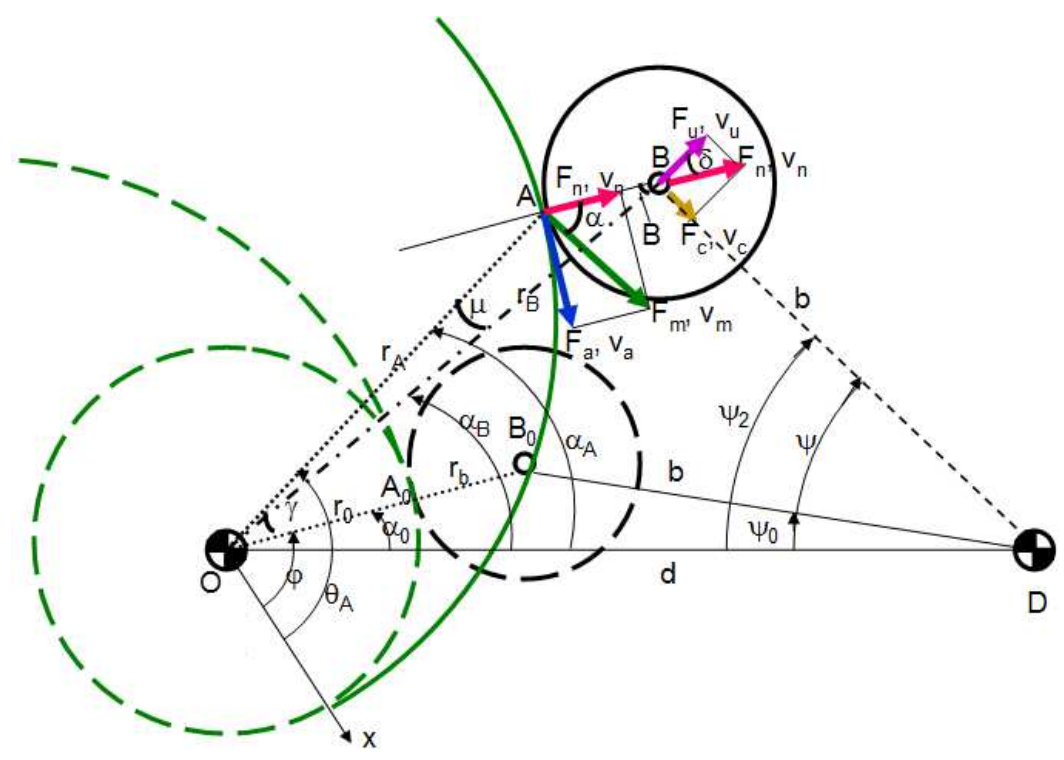

Fig. 2. Forces and velocities of the mechanism

Instantly mechanical efficiency is the square of the product of the cosines of the two pressure angles $\alpha$ and $\delta$, or is the fourth power of the pressure $\delta$ angle amplified with a variable, $\frac{\psi^{\prime 2} \cdot b^{2}}{r_{A}^{2}}$.

\section{Determination of the Transfer Function of the Movement}

Next is determined the function of motion transmitting (the transmissivity function or coefficient) to the rotating cam mechanism and rotating follower with roller ( $F$ module), function denoted by $D$.
Between helpful velocity $\left(v_{u}\right)$ and known velocity $\left(v_{2}\right)$ of the tappet occurs a difference, which must be embedded in the transmission coefficient $D$, or the transmission function $D$ (Petrescu, 2015a).

Write the tappet reduced velocity $v_{B 2 r}$ in the form known (3):

$$
v_{B 2 r}=\frac{v_{B 2}}{\omega}=b \cdot \psi^{\prime}
$$

Absolute speed tappet in B (relation 4) is obtained by multiplying the reduced speed (3) with $\omega$ : 


$$
v_{B 2}=b \cdot \psi^{\prime} \cdot \omega
$$

One will write this velocity in its dynamic form (actual 5), together with a coefficient of motion transmission, $D$ :

$$
v_{2}=b \cdot \psi^{\prime} \cdot D \cdot \omega
$$

Useful speed obtained from system 1 (and Fig. 2) may be represented in the form 6:

$$
\left\{\begin{array}{l}
v_{m}=r_{A} \cdot \dot{\theta}_{A}=r_{A} \cdot \theta_{A}^{\prime} \cdot \omega \text { dynamic obtained } \\
v_{u}=v_{m} \cdot \cos \alpha \cdot \cos \delta= \\
=v_{m} \cdot \frac{b \cdot \psi^{\prime}}{r_{A}} \cdot \cos ^{2} \delta= \\
=\theta_{A}^{\prime} \cdot \omega \cdot b \cdot \psi^{\prime} \cdot \cos ^{2} \delta= \\
=b \cdot \psi^{\prime} \cdot \theta_{A}^{\prime} \cdot \cos ^{2} \delta \cdot \omega
\end{array}\right.
$$

Two speeds (5-6) equaling gets the expression of transmission (dynamic) coefficient $D$ (relation 7):

$$
D=\theta_{A}^{\prime} \cdot \cos ^{2} \delta
$$

Considering classical variant (without dynamic input), when $v_{m}=r_{A} \cdot \omega$, the dynamic coefficient $D$ takes the simplified value (8):

$$
D=\cos ^{2} \delta
$$

\section{Dynamics of Module F}

For the dynamic calculations one uses the below original relations (9-11) obtained by a double integration of the Newton equation:

$\Delta X$

$$
=-\frac{\frac{k^{2}+2 k K}{(K+k)^{2}} \cdot s^{2}+\frac{2 k x_{0}}{K+k} \cdot s+\frac{\left[\frac{K^{2}}{(K+k)^{2}} \cdot m_{S}^{*}+m_{T}^{*}\right] \cdot \omega^{2}}{K+k} \cdot y^{\prime 2}}{2 \cdot\left[s+\frac{k x_{0}}{K+k}\right]}
$$

$$
\Delta X
$$

$$
\begin{aligned}
& \frac{k^{2}+2 k K}{(K+k)^{2}} \cdot s^{2}+\frac{2 k x_{0}}{K+k} \cdot s \\
& =-\frac{+\frac{\left[\frac{K^{2}}{(K+k)^{2}} \cdot m_{S}^{*}+m_{T}^{*}\right] \cdot \omega^{2}}{K+k} \cdot\left(D \cdot s^{\prime}\right)^{2}}{2 \cdot\left[s+\frac{k x_{0}}{K+k}\right]}
\end{aligned}
$$

Determining $\Delta X$ it can calculating then $X$ with expression (11):

$X=s+\Delta X$

Where:

$s=$ The theoretical tappet movement law and $x$ is the real (dynamic) tappet movement law

$K=$ The elastic constant of the system and $k$ is the elastic constant of the valve spring

$x_{0}=$ The valve spring pretension

$m_{S}^{*}=$ The valve mass reduced at the valve axis

$m_{T}^{*}=$ The tappet mass reduced at the valve axis

Then we must convert the rotation moving of the tappet into a translation moving of the valve (Fig. 3 and relations 12-13):

$l=\frac{b}{i}$

$\left\{\begin{array}{l}s=\frac{b}{i} \cdot \psi \\ s^{\prime}=\frac{b}{i} \cdot \psi^{\prime} \\ s^{\prime \prime}=\frac{b}{i} \cdot \psi^{\prime \prime} \\ s^{\prime \prime \prime}=\frac{b}{i} \cdot \psi^{\prime \prime}\end{array}\right.$,

\section{Dynamic Analysis of the Module F}

The dynamic analysis begins with the classical law sine (see diagram of the Fig. 4 and the profile of the Fig. $5)$, to can be compared with the known law dynamic module $\mathrm{C}$ classic.

It uses a drive shaft rotation speed of $\mathrm{n}=5500$ $[\mathrm{r} / \mathrm{min}]$, the theoretical maximum displacement for both the valve and the tappet, $\mathrm{h}=10[\mathrm{~mm}]$. The phase angle is $\varphi_{\mathrm{u}}=\varphi_{\mathrm{c}}=60$ [degree]; core radius has value $\mathrm{r}_{0}=24$ [mm]. Roll radius has been adopted the value $\mathrm{r}_{\mathrm{b}}=20[\mathrm{~mm}] ; \mathrm{b}=$ $20[\mathrm{~mm}] ; \mathrm{d}=50[\mathrm{~mm}]$. Valve spring adjustments are: $\mathrm{k}=$ $60[\mathrm{~N} / \mathrm{mm}]$ şi $\mathrm{x}_{0}=30[\mathrm{~mm}]$. The yield has a high value, $\eta=12.0 \%$.

Dynamic is better (in general) compared with that of the module classic, $C$, in conditions in that the real movement of the valve, s, almost doubled!

For the law cosine lifting is higher as compared with the law sine. See the Fig. 6 and 7.

In the Fig. 8 one can see the dynamic analysis of the original law denominated by the authors C4P1-0 and in the Fig. 9 the corresponding profile.

Opening of the valve is less, but the yield mechanism has increased. 


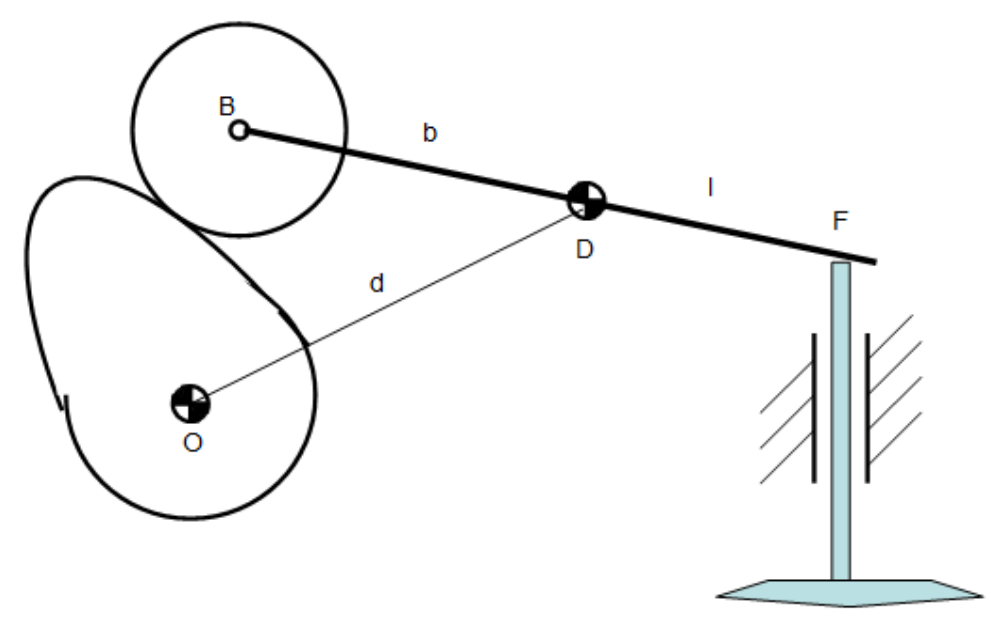

Fig. 3. Converting the rotation moving of the tappet into a translation moving of the valve (Simplified diagram)

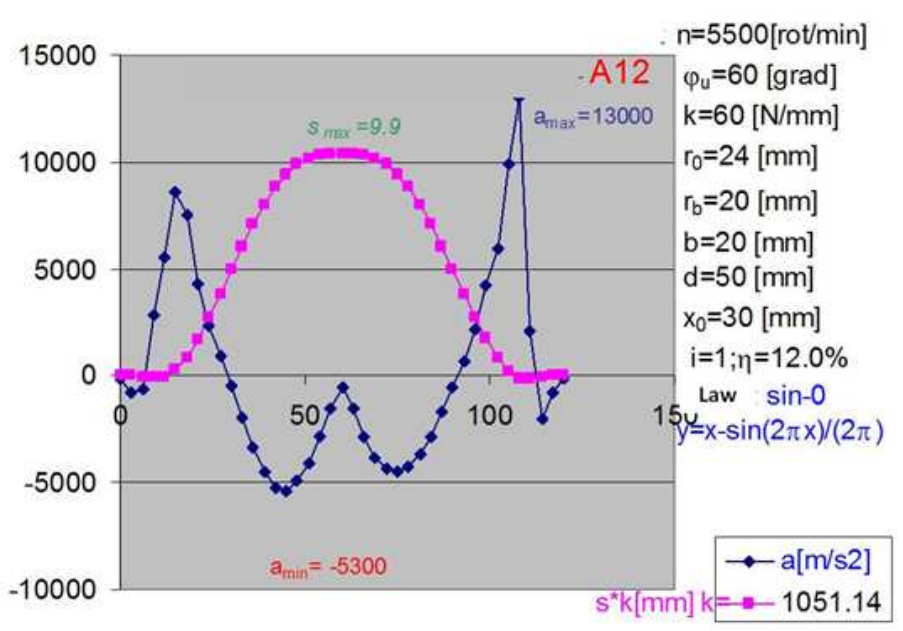

Fig. 4. Dynamic analysis of the module F. Law Sine, $\mathrm{n}=5500[\mathrm{rot} / \mathrm{min}], \varphi_{\mathrm{u}}=60[\mathrm{deg}], \mathrm{r}_{0}=24[\mathrm{~mm}], \mathrm{r}_{\mathrm{b}}=20[\mathrm{~mm}]$

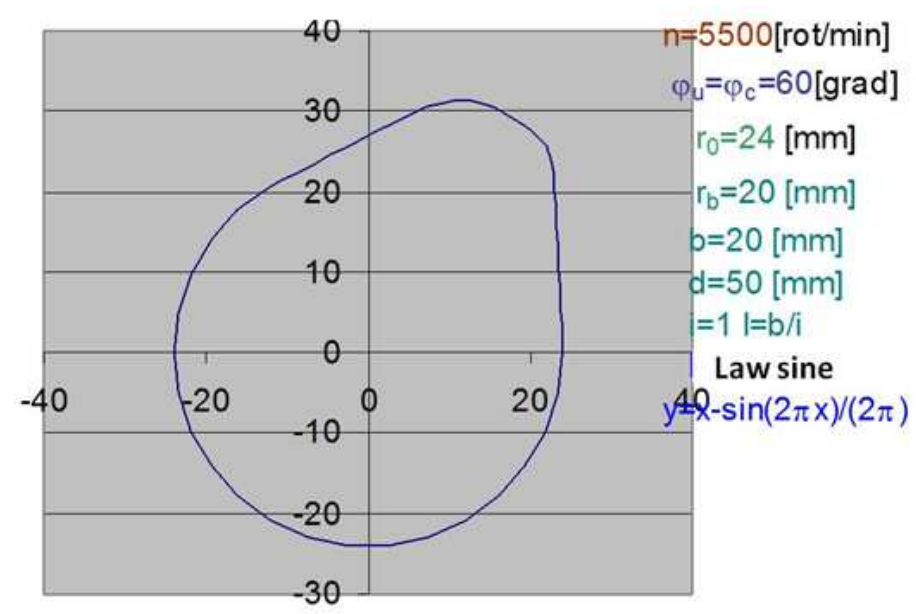

Fig. 5. Cam profile of the module F. Law Sine, $\varphi_{\mathrm{u}}=60[\mathrm{deg}], \mathrm{r}_{0}=24[\mathrm{~mm}], \mathrm{r}_{\mathrm{b}}=20[\mathrm{~mm}]$ 


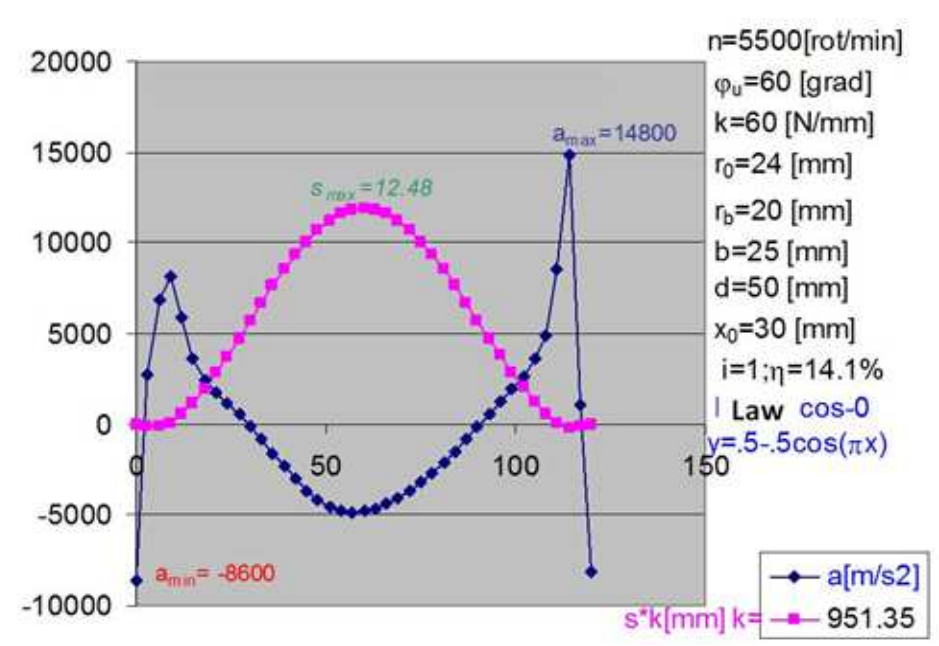

Fig. 6. Dynamic analysis of the module F. Law Cosine, $n=5500$ [rot $/ \mathrm{min}], \varphi_{\mathrm{u}}=60$ [deg], $\mathrm{r}_{0}=24[\mathrm{~mm}], \mathrm{r}_{\mathrm{b}}=20[\mathrm{~mm}]$

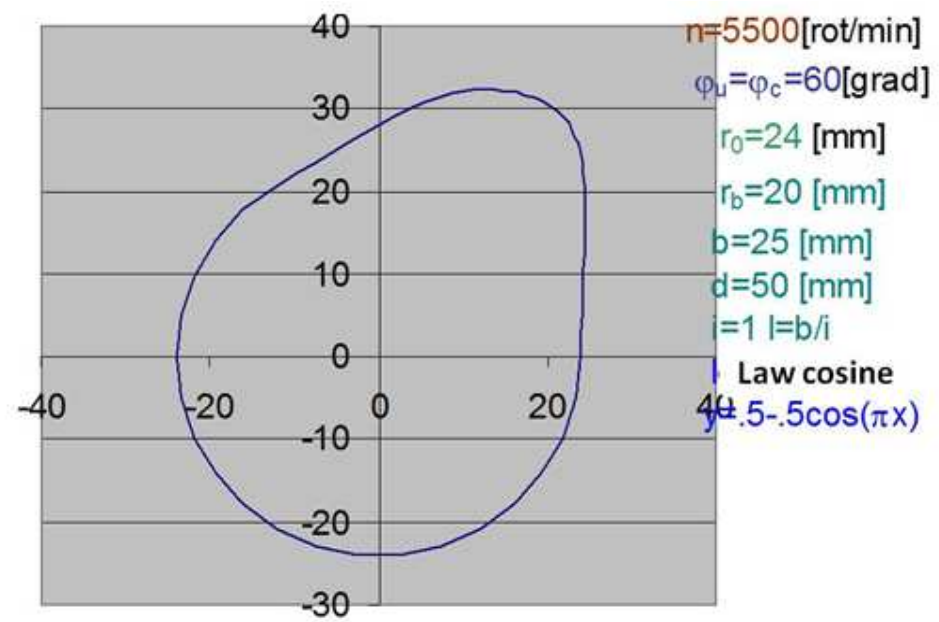

Fig. 7. Cam profile of the module F. Law Sine, $\varphi_{u}=60[\mathrm{deg}], \mathrm{r}_{0}=24[\mathrm{~mm}], \mathrm{r}_{\mathrm{b}}=20[\mathrm{~mm}]$

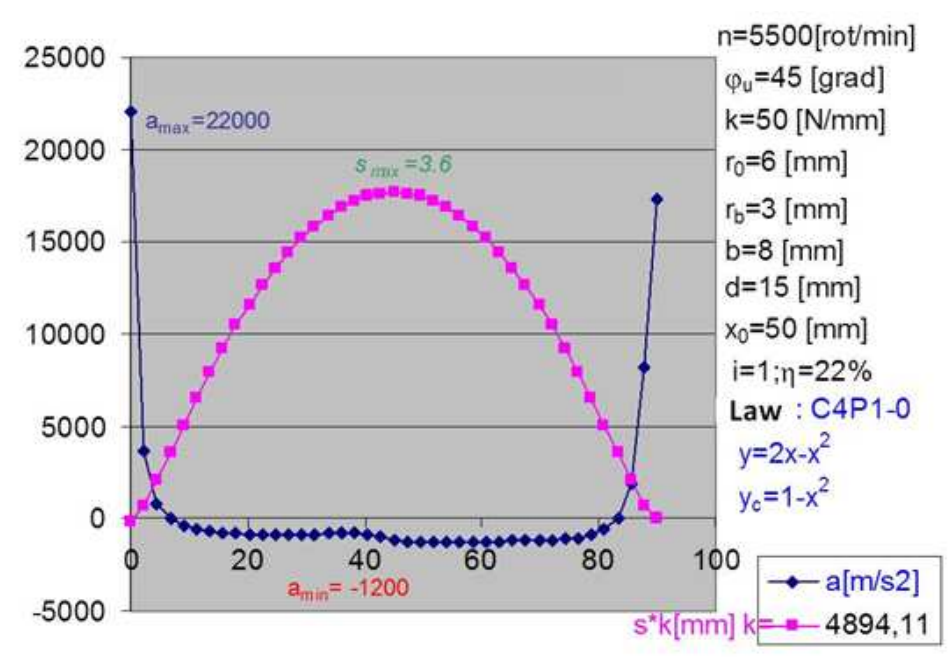

Fig. 8. Dynamic analysis of the module F. Law C4P1-0, $\mathrm{n}=5500$ [rot $/ \mathrm{min}], \varphi_{\mathrm{u}}=45[\mathrm{deg}], \mathrm{r}_{0}=6[\mathrm{~mm}], \mathrm{r}_{\mathrm{b}}=3[\mathrm{~mm}]$ 


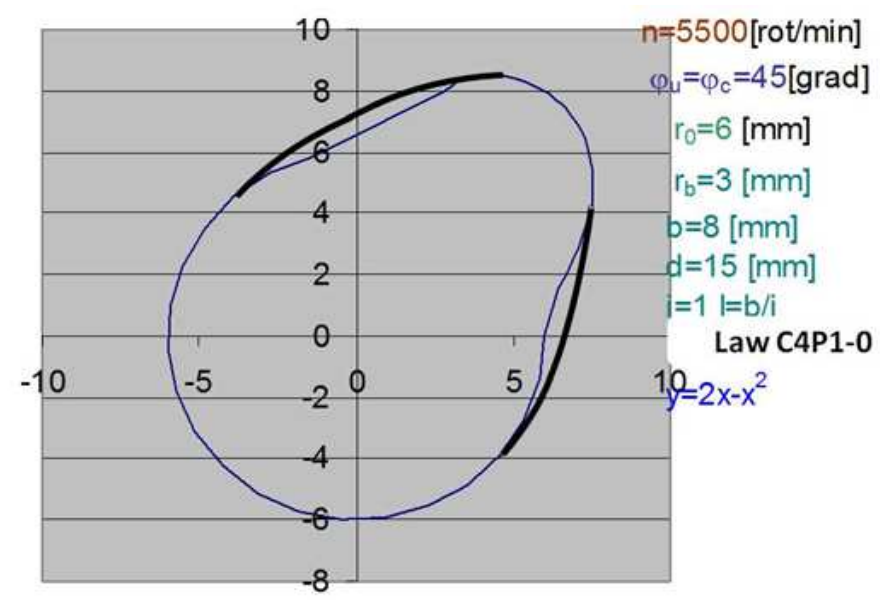

Fig. 9. Cam profile of the module F. Law C4P1-0, $\varphi_{u}=45[\mathrm{deg}], \mathrm{r}_{0}=6[\mathrm{~mm}], \mathrm{r}_{\mathrm{b}}=3[\mathrm{~mm}]$

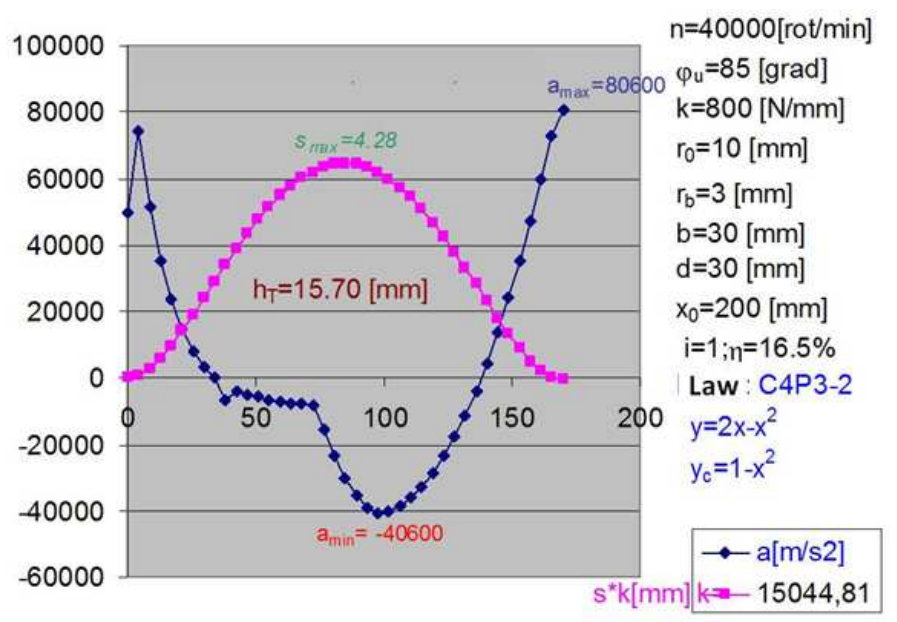

Fig. 10. Dynamic analysis of the module F. Law C4P3-2, $\mathrm{n}=40000[\mathrm{rot} / \mathrm{min}], \varphi_{\mathrm{u}}=85[\mathrm{deg}], \mathrm{r}_{0}=10[\mathrm{~mm}], \mathrm{r}_{\mathrm{b}}=3[\mathrm{~mm}]$

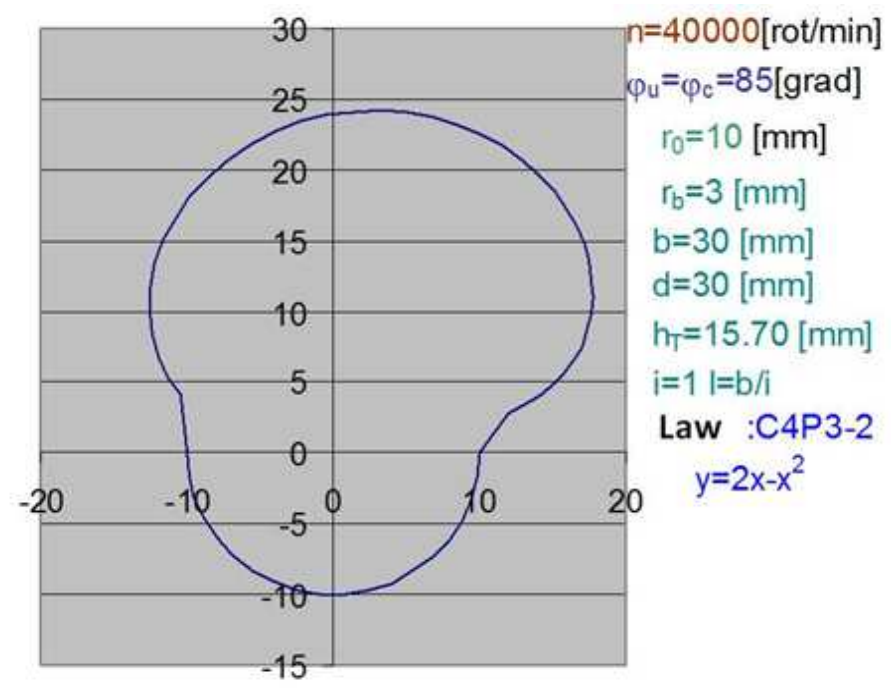

Fig. 11. Cam profile of the module F. Law C4P3-2, $\varphi_{u}=85[\mathrm{deg}], \mathrm{r}_{0}=10[\mathrm{~mm}], \mathrm{r}_{\mathrm{b}}=3[\mathrm{~mm}]$ 
In the Fig. 10 one can see the dynamic analysis of the original law denominated by the authors C4P3-2 and in the Fig. 11 the corresponding profile.

This last presented law, allow the increase of the drive shaft rotation speed to the $40000 \mathrm{rot} / \mathrm{min}$.

\section{Discussion}

The distribution mechanism with rotation cam and rotating tappet with roll, allow us the increasing the rotation speed of the drive shaft and the increasing of the mechanical yield of the couple cam-tappet.

This type of distribution mechanism allow and the construction of a compact motor (engine), which may work with high power producing a level of noxious gases lowest and a fuel consumption decreased as well.

Even the higher accelerations produced by these conditions may by increased by the valve spring adjustments.

These adjustments may be provided for some special dynamic calculation with an improved dynamic system, new created by authors.

The secret is appropriate increase in those two values: $k$ and $x_{0}$.

As long as we produce electricity and heat by burning fossil fuels is pointless to try to replace all thermal engines with electric motors, as loss of energy and pollution will be even larger.

However, it is well to continuously improve the thermal engines, to reduce thus fuel consumption.

At the heat engine with internal combustion a great loss of power is realized and by the distribution mechanism, reason for that we must try to improve the functionality of this mechanism.

As a computer program was used specialized software from Microsoft Excel (see Appendix).

\section{Benefits}

The main advantage is that the $\mathrm{F}$ module supports a much higher speed compared to classic mode (An engine with high rotation speed can be more compact, more powerful and more economical and without nuisance).

In addition at this mechanism (cam module F) and efficiency is higher.

\section{Conclusion}

At the heat engine with internal combustion a great loss of power is realized and by the distribution mechanism, reason for that we must try to improve the functionality of this mechanism.

The dynamic synthesis of this type of distribution mechanism can be made shortly, by the Cartesian coordinates, but to determine these coordinates we need and some trigonometric parameters of the mechanism.

The paper presents shortly an original trigonometric method to make the synthesis of a mechanism with rotary cam and rotated tappet with roll, used with priority at the distribution mechanisms from the heat engines with internal combustion.

This type of distribution can improve the changes of gases and may decrease significantly the level of vibration, noises and emissions.

The main advantage is that the $F$ module supports a much higher speed compared to classic mode (An engine with high rotation speed can be more compact, more powerful and more economical and without nuisance).

In addition at this mechanism (cam module $F$ ) and efficiency is higher.

\section{Acknowledgement}

This text was acknowledged and appreciated by Dr. Veturia CHIROIU Honorific member of Technical Sciences Academy of Romania (ASTR) PhD supervisor in Mechanical Engineering and by the collectives of mechanisms of TMR departments from Bucharest, Brasov, Cluj-Napoca, Craiova, Iasi, from Romania and by Prof. Georgios E. STAVROULAKIS, Department of Production Engineering and Management, Rector of the Technical University of Crete, Greece, who showed that "The Paper is well written." and Ahad Esmaeilian, Texas A\&M University, which said "The paper is well written and well presented. The idea looks interesting and promising." whom we thank and in this way.

\section{Funding Information}

Research contract: Contract number 36-5-4D/1986 from 24IV1985, beneficiary CNST RO (Romanian National Center for Science and Technology) Improving dynamic mechanisms internal combustion engines.

\section{Author's Contributions}

Florian Ion T. Petrescu: Participated in all experiments, coordinated the data-analysis and contributed to the writing of the manuscript, especially of the calculation equations.

John Kaiser Calautit: Participated in all experiments, coordinated the data-analysis and contributed to the writing of the manuscript including the English correction.

Dragan Marinkovic: Coordinated the data-analysis and contributed to the writing of the excel programs. 


\section{Ethics}

This article is original and contains unpublished material. Author declares that are not ethical issues that may arise after the publication of this manuscript.

\section{References}

Amoresano, A., V. Avagliano, V. Niola and G. Quaremba, 2013. The assessment of the in-cylinder Pressure by means of the morpho-dynamical vibration analysis-methodology and application. IREME J., 7: 999-1006.

Anderson, R.B., H. Kölbel and M. Rálek, 1984. The Fischer-Tropsch Synthesis. 1st Edn., Academic Press, Orlando, ISBN-10: 0120584603, pp: 301.

Angelas, J. and C. Lopez-Cajun, 1988. Optimal synthesis of cam mechanisms with oscillating flat-face followers. Mechanism Machine Theory, 23: 1-6. DOI: 10.1016/0094-114X(88)90002-X

Antonescu, P., F. Petrescu and O. Antonescu, 2000. Contributions to the synthesis of the rotary disccam profile. Proceedings of the 8th International Conference on the Theory of Machines and Mechanisms, (TMM' 00), Liberec, Czech Republic, pp: 51-56.

Antonescu, P., M. Oprean and F.I. Petrescu, 1987. Analiza dinamică a mecanismelor de distribuție cu came. Proceedings al 7-lea Simpozion National de Roboti Industriali, (NRI' 87), București, pp: 126-133.

Barzegari, A., 2011. A new algorithm based on particle swarm optimization for solving power economic dispatch considering valve-point effects and emission constraints. I.RE.MO.S. J., 4: 1303-1311.

Bishop, J.L.H., 1950. An analytical approach to automobile. valve gear design. Proc. Instit. Mechan. Eng., 4: 150-160.

DOI: 10.1243/PIME AUTO 195000001802

Choi, J.K. and S.C. Kim, 1994. An experimental study on the frictional characteristics in the valve train system. Proceedings of the 1st Congress, Oct. 17-21, Beijing, pp: 374-380.

De Falco, D., G. Di Massa, S. Pagano and S. Strano, 2013a. Motorcycle handlebar dynamic response: Theoretical and experimental investigation. IREME J., 7: 795-801.

De Falco, D., G. Di Massa and S. Pagano, 2013b. A full scale motorcycle dynamic rig. IREME J., 7: 519-526.

Ganapathi, P. and Y. Robinson, 2013. Experimental investigation of performance and emission characteristics of DI diesel engine fueled with polymer waste dissolved in biodiesel-blended diesel fuel. IREME J., 7: 919-924.

DOI: $10.1016 / \mathrm{j}$.energy.2012.07.049
Giordana, F., V. Rognoni and G. Ruggieri, 1979. On the influence of measurement errors in the Kinematic analysis of cams. Mechanism Machine Theory, 14: 327-340. DOI: 10.1016/0094-114X(79)90019-3

Hain, K., 1971. Optimization of a cam mechanism-to give good transmissibility, maximal output angle of swing and minimal acceleration. J. Mechanisms, 6: 419-434. DOI: 10.1016/0022-2569(71)90044-9

Heywood, J.B., 1988. Internal Combustion Engine Fundamentals. 1st Edn., McGraw-Hill, New York, ISBN-10: 007028637X, pp: 930.

Hrones, J.A., 1948. An analysis of dynamic forces in a cam-driver system. Trans. ASME, 70: 473-482.

Karikalan, L., M. Chandrasekaran and K. Sudhagar, 2013. Comparative studies on vegetable oil usage in C.I engines as an alternative to diesel fuel. IREME J., 7: 705-715.

Leidel, J.A., 1997. An optimized low heat rejection engine for automotive use-an inceptive study. SAE International.

Mahalingam, S. and B.R. Ramesh Bapu, 2013. Experimental and emission analysis of rubber seed oil and Jatropha oil blends with diesel in compression ignition engine. IREME J., 7: 955-959.

Naima, K. and A. Liazid, 2013. Numerical investigation on combustion behaviors of direct-injection spark ignition engine fueled with CNG-hydrogen blends. IREME J., 7: 652-663.

Narasiman, V., S. Jeyakumar and M. Mani, 2013. Optimizing the compression ratio of C.I engine fuelled in sardine oil ethyl ester. IREME J., 7: 463-467.

Petrescu, F. and R. Petrescu, 1995. Contributii la sinteza mecanismelor de distributie ale motoarelor cu ardere interna.

Petrescu, F.I. and R.V. Petrescu, 2005a. Contributions at the dynamics of cams. Proceedings of the 9th IFToMM International Symposium on Theory of Machines and Mechanisms, (TMM' 05), Bucharest, Romania, pp: 123-128.

Petrescu, F.I. and R.V. Petrescu, 2005b. Determining the dynamic efficiency of cams. Proceedings of the 9th IFToMM International Symposium on Theory of Machines and Mechanisms, (TMM' 05), Bucharest, Romania, pp: 129-134.

Petrescu, F.I., R.V. Petrescu and N. Popescu, 2005. The efficiency of cams. Proceedings of the 2nd International Conference "Mechanics and Machine Elements", Nov. 4-6, Technical University of Sofia, Sofia, Bulgaria, pp: 237-243.

Petrescu, F.I., 2008. Cams Dynamic Efficiency Determination. In: New Trends in Mechanisms, Academica-Greifswald, ISBN-13: 978-3-940237-10-1, pp: 49-56. 
Petrescu, F.I. and R.V. Petrescu, 2011. Dinamica mecanismelor de distributie. Create Space Publisher, USA.

Petrescu, F.I., 2012a. Bazele analizei $\square$ i optimizării sistemelor cu memorie rigidă-curs $\square$ i aplica $\square$ ii. Create Space Publisher, USA.

Petrescu, F.I., 2012b. Teoria mecanismelor-Curs si aplicatii (editia a doua). Create Space Publisher, USA.

Petrescu, F.I. and R.V. Petrescu, 2013a. An algorithm for setting the dynamic parameters of the classic distribution mechanism. IREMOS J., 6: 1637-1641.

Petrescu, F.I. and R.V. Petrescu, 2013b. Dynamic synthesis of the rotary cam and translated tappet with roll. IREMOS J., 6: 600-607.

Petrescu, F.I. and R.V. Petrescu, 2013c. Forces and efficiency of cams. IREME, 7: 507-511.

Petrescu, F.I. and R.V. Petrescu, 2013d. Cams with high efficiency. IREME, 7: 599-606.

Petrescu, F.I. and R.V. Petrescu, 2014. Cam gears dynamics in the classic distribution. Independent $\mathrm{J}$. Manage. Product., 5: 166-185.

DOI: 10.14807/ijmp.v5il.133

Petrescu, F.I., 2015a. Geometrical synthesis of the distribution mechanisms. Am. J. Eng. Applied Sci., 8: 63-81. DOI: 10.3844/ajeassp.2015.63.81

Petrescu, F.I., 2015b. Machine motion equations at the internal combustion heat engines. Am. J. Eng. Applied Sci., 8: 127-137. DOI: 10.3844/ajeassp.2015.127.137

Rahmani, L., B. Draoui, M. Bouanini and E. Benachour, 2013. CFD study on heat transfer to Bingham fluid during with gate impeller. IREME, 7: 1074-1079.

Ravi, S. and R. Subramanian, 2013. Diesel fuel additives: An overview. IREME, 7: 698-704.

Ronney, P.D., M. Shoda, S.T. Waida and E.J. Durbin, 1994. Throttleless premixed-charge engines: Concept and experiment. J. Automobile Eng., 208: 13-24. DOI: 10.1243/PIME_PROC_1994_208_153_02

Samim, Y. and S.T. Tu $\square$ mer, 1993. Analytical dynamic response of elastic cam-follower systems with distributed parameter Return spring. J. Mech. Design, 115: 612-620. DOI: 10.1115/1.2919234

Sapate, K.D. and A.N. Tikekar, 2013. Engine mapping for improvement in fuel efficiency of two stroke SI engine. IREME, 7: 392-394.

Sethusundaram, P.P., K.P. Arulshri and K. Mylsamy, 2013. Biodiesel blend, fuel properties and its emission characteristics sterculia oil in diesel engine. IREME, 7: 925-929.

Shriram, R., 2012. Design and development of camless valve train for I.C. engines. IREME J., 6: 1044-1049.

Taraza, D., 2002. Accuracy limits of IMEP determination from crankshaft speed measurements. SAE Trans. J. Engines, 111: 689-697.
Wang, W., 2011. Creation design of cam mechanism based on reverse engineering. Adv. Mater. Res. J., 230-232: 453-456.

DOI: 10.4028/www.scientific.net/AMR.230-232.453

Xianying, F., 2011. Meshing efficiency of globoidal indexing cam mechanism with steel ball. Adv. Mater. Res. J., 413: 414-419.

DOI: $10.4028 / w w w . s c i e n t i f i c . n e t / A M R .413 .414$

Zahari, I., M.A. Abras, N.I. Mat Arishad, S.F. Zainal and M.F. Muhamad, 2013. Experimental study to identify common engine part load conditions between Malaysian city driving and NEDC test. IREME, 7: 1152-1158.

Zhao, H.D., C. Huang, M. Chen, J. Li and G. Hun, 2012. Research on dynamic behavior of disc indexing cam mechanism based on virtual prototype technology. Key Eng. Mater. J., 499: 277-282.

DOI: 10.4028/www.scientific.net/KEM.499.277

\section{Nomenclature}

$\mathrm{M}$

$=$ the mass of the mechanism, reduced at the valve

$\mathrm{K}=$ the elastically constant of the system

$\mathrm{k}=$ the elastically constant of the valve spring

c $=$ the coefficient of the system's amortization

$\mathrm{F}_{0} \quad=$ the elastically force which compressing the valve spring

$\mathrm{x}=$ the effective displacement of the valve

$\mathrm{x}_{0} \quad=$ the valve (tappet) spring preload

$\mathrm{x}^{\prime} \quad=$ the reduced valve (tappet) speed

$\mathrm{x} ", \quad=$ the reduced valve (tappet) acceleration

$\mathrm{y} \equiv \mathrm{s} \quad=\quad$ the theoretical displacement of the tappet reduced at the valve, imposed by the cam's profile

$\mathrm{m}_{\mathrm{T}}=\mathrm{m}_{2}=$ the mass of the tappet (of the valve lifter);

$\mathrm{m}_{3} \quad=$ the mass of the valve push rod

$\mathrm{m}_{5} \quad=$ the valve mass

$\mathrm{J}_{1}=$ the inertia mechanical moment of the cam

$\mathrm{J}_{4}=$ the inertia mechanical moment of the valve rocker

$\dot{y}_{2}=$ the tappet velocity, or the second movement-low, imposed by the cam's profile

$\dot{x}=$ the real (dynamic) valve velocity

$\mathrm{i}=\mathrm{i}_{25}=$ the ratio of transmission tappet-valve, given from the valve rocker

$\begin{array}{ll}\dot{y} & =\text { the tappet velocity reduced at the valve } \\ \omega & =\text { the angular rotation speed of the cam (or }\end{array}$ camshaft)

$D=$ the dynamic transmission function (the dynamic transmission coefficient)

$\dot{D}=$ the derivative of $\mathrm{D}$ in function of the time 


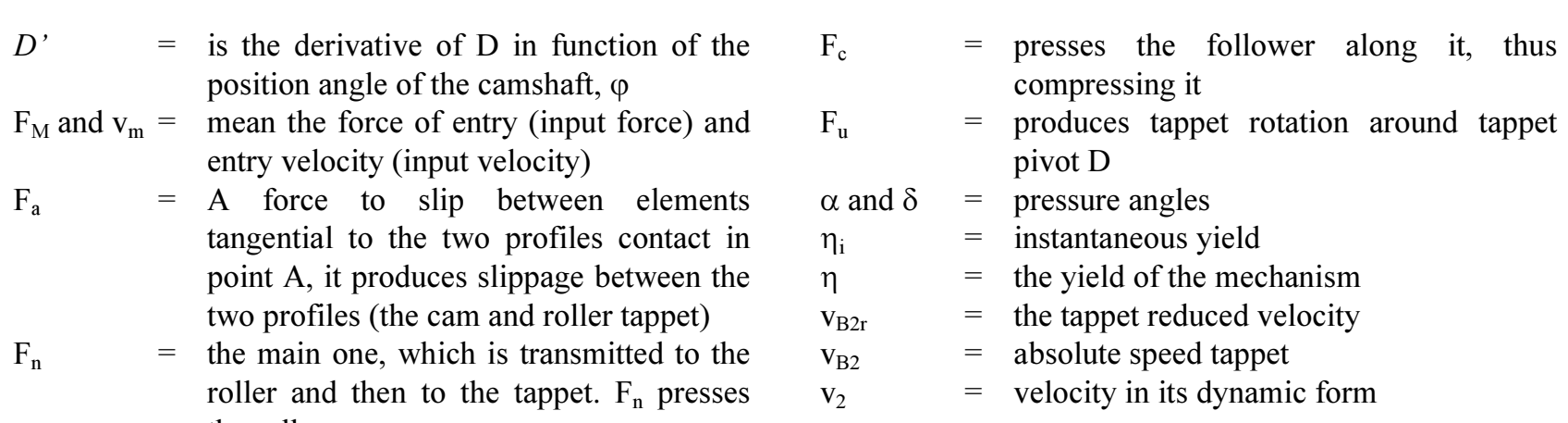

\section{Appendix}

A computer program written on specialized software from Microsoft Excel for rotating cam and rocker tappet with roller (Module F)

\begin{tabular}{|c|c|c|}
\hline 1 & $\mathrm{n}[\mathrm{rot} / \mathrm{min}]$ & $=5500$ \\
\hline 2 & $\varphi_{\mathrm{u}}[\mathrm{rad}]$ & $=\mathrm{PI}() / 180 * 60$ \\
\hline 3 & $\mathrm{k}[\mathrm{N} / \mathrm{mm}]$ & $=60$ \\
\hline 4 & $\eta$ & $=\mathrm{SUM}(\mathrm{B} 83: \mathrm{AP} 83) / 41$ \\
\hline 5 & $\mathrm{~K}[\mathrm{~N} / \mathrm{mm}]$ & $\begin{array}{l}=1 /\left(1 /\left(\mathrm{B} 110^{*} \mathrm{~B} 28^{\wedge} 2\right)+1 /\left(\mathrm{B} 111^{*} \mathrm{~B} 28^{\wedge} 2\right)\right. \\
\left.+1 /\left(\mathrm{B} 112^{*} \mathrm{~B} 28^{\wedge} 2\right)+1 / \mathrm{B} 113+1 / \mathrm{B} 114\right)\end{array}$ \\
\hline 6 & $\mathrm{r}_{0}[\mathrm{~mm}]$ & $=24$ \\
\hline 7 & $\mathrm{x}_{0}[\mathrm{~mm}]$ & $=30$ \\
\hline 8 & $\psi_{\mathrm{M}}[\mathrm{rad}]$ & $=\mathrm{PI}() / 180 * 30$ \\
\hline 9 & $\mathrm{~m} *[\mathrm{~kg}]$ & $=\mathrm{B} 10+\mathrm{B} 11$ \\
\hline 10 & $\mathrm{~m}_{\mathrm{LS}} *[\mathrm{~kg}]$ & $=\mathrm{B} 104+\mathrm{B} 105+1 / 3 * \mathrm{~B} 106+\mathrm{B} 107 /(\mathrm{B} 28+1)$ \\
\hline 11 & $\mathrm{~m}_{\mathrm{LT}} *[\mathrm{~kg}]$ & $=\mathrm{B} 28^{\wedge} 2^{*}\left(\mathrm{~B} 108+\mathrm{B} 109+\mathrm{B} 28^{*} \mathrm{~B} 107 /(\mathrm{B} 28+1)\right)$ \\
\hline 12 & $\omega_{n}\left[\mathrm{~s}^{-1}\right]$ & $=\mathrm{PI}()^{*} \mathrm{~B} 1 / 60$ \\
\hline 13 & $\omega_{n}^{2}\left[s^{-2}\right]$ & $=\mathrm{B} 12^{\wedge} 2$ \\
\hline 14 & $\Delta x[]$ & $=0,05$ \\
\hline 15 & $\mathrm{x}[]$ & $=0$ \\
\hline 16 & $\mathrm{y}[]$ & $=\mathrm{B} 15-\mathrm{SIN}(\mathrm{B} 15 * \mathrm{PI}() * 2) /(2 * \mathrm{PI}())$ \\
\hline 17 & $y^{\prime}[]$ & $=1-\operatorname{COS}(2 * \mathrm{PI}() * \mathrm{~B} 15)$ \\
\hline 18 & $\mathrm{y}^{\prime \prime}[]$ & $=2 * \operatorname{PI}() * \operatorname{SIN}(2 * \operatorname{PI}() * \mathrm{~B} 15)$ \\
\hline 19 & $y^{\prime \prime \prime}[]$ & $=4 * \operatorname{PI}()^{\wedge} 2 * \operatorname{COS}\left(2 * \operatorname{PI}()^{*} \mathrm{~B} 15\right)$ \\
\hline 20 & $\mathrm{y}^{\mathrm{IV}}[]$ & $=-8 * \operatorname{PI}()^{\wedge} 3 * \operatorname{SIN}(2 * \operatorname{PI}() * \mathrm{~B} 15)$ \\
\hline 21 & $\mathrm{y}^{\mathrm{V}}[]$ & $=-16 * \mathrm{PI}()^{\wedge} 4 * \operatorname{COS}\left(2 * \mathrm{PI}()^{*} \mathrm{~B} 15\right)$ \\
\hline 22 & $\psi[\mathrm{mm}]$ & $=\mathrm{B} 16^{*} \mathrm{~B} 8$ \\
\hline 23 & $\psi^{\mathrm{I}}[\mathrm{mm}]$ & $=\mathrm{B} 17 * \mathrm{~B} 8 / \mathrm{B} 2$ \\
\hline 24 & $\psi^{\mathrm{II}}[\mathrm{mm}]$ & $=\mathrm{B} 18^{*} \mathrm{~B} 8 / \mathrm{B} 2^{\wedge} 2$ \\
\hline 25 & $\psi^{\mathrm{III}}[\mathrm{mm}]$ & $=\mathrm{B} 19^{*} \mathrm{~B} 8 / \mathrm{B} 2^{\wedge} 3$ \\
\hline 26 & $\psi^{\mathrm{IV}}[\mathrm{mm}]$ & $=\mathrm{B} 20 * \mathrm{~B} 8 / \mathrm{B} 2 \wedge 4$ \\
\hline 27 & $\psi^{\mathrm{V}}[\mathrm{mm}]$ & $=\mathrm{B} 21^{*} \mathrm{~B} 8 / \mathrm{B} 2^{\wedge} 5$ \\
\hline 28 & $\mathrm{i}[]$ & $=1$ \\
\hline 30 & $\mathrm{~K}_{\mathrm{v}}[\mathrm{N} / \mathrm{mm}]$ & $\begin{array}{l}=1 /\left(\left(1 /\left(20^{*} \mathrm{PI}()^{*}(\mathrm{~B} 6+\mathrm{B} 8 / 2)^{\wedge} 2\right)+\right.\right. \\
\left.1 / 72871)^{*} \mathrm{~B} 23^{\wedge} 2 /(\mathrm{B} 6+\mathrm{B} 22)^{\wedge} 2+1 / \mathrm{B} 5\right)\end{array}$ \\
\hline 31 & $\mathrm{~b}[\mathrm{~mm}]$ & $=25$ \\
\hline 32 & $\mathrm{~d}[\mathrm{~mm}]$ & $=30$ \\
\hline 33 & $\mathrm{r}_{\mathrm{b}}[\mathrm{mm}]$ & $=8$ \\
\hline 34 & $\psi_{0}[\mathrm{rad}]$ & $\begin{array}{l}=\mathrm{ACOS}\left(\left(\mathrm{B} 31^{\wedge} 2+\mathrm{B} 32^{\wedge} 2-(\mathrm{B} 6+\mathrm{B} 33)^{\wedge} 2\right)\right. \\
\left./\left(2^{*} \mathrm{~B} 31^{*} \mathrm{~B} 32\right)\right)\end{array}$ \\
\hline 35 & $\psi_{2}[\mathrm{rad}]$ & $=\mathrm{B} 22+\mathrm{B} 34$ \\
\hline 36 & $\cos \psi_{2}$ & $=\cos (\mathrm{B} 35)$ \\
\hline 37 & $\sin \psi_{2}$ & $=\operatorname{SIN}(\mathrm{B} 35)$ \\
\hline 38 & $1-\psi^{\prime}$ & $=1-\mathrm{B} 23$ \\
\hline
\end{tabular}




\begin{tabular}{|c|c|c|}
\hline 39 & RAD $\delta$ & $\begin{array}{l}=\mathrm{SQRT}\left(\mathrm{B} 32^{\wedge} 2+\mathrm{B} 31^{\wedge} 2^{*} * \mathrm{~B} 38^{\wedge} 2\right. \\
\left.-2 * \mathrm{~B} 31^{*} \mathrm{~B} 32^{*} \mathrm{~B} 38^{*} \mathrm{~B} 36\right)\end{array}$ \\
\hline 40 & $\sin \delta$ & $=(\mathrm{B} 32 * \mathrm{~B} 36-\mathrm{B} 31 * \mathrm{~B} 38) / \mathrm{B} 39$ \\
\hline 41 & $\cos \delta$ & $=\mathrm{B} 32 * \mathrm{~B} 37 / \mathrm{B} 39$ \\
\hline 42 & $\operatorname{tg} \delta$ & $=(\mathrm{B} 32 * \mathrm{~B} 36-\mathrm{B} 31 * \mathrm{~B} 38) /(\mathrm{B} 32 * \mathrm{~B} 37)$ \\
\hline \multirow[t]{2}{*}{43} & $\delta^{\prime}$ & $=(\mathrm{B} 31 * \mathrm{~B} 24-\mathrm{B} 32 * \mathrm{~B} 37 * \mathrm{~B} 23-\mathrm{B} 32 *$ \\
\hline & & $\mathrm{B} 42 * \mathrm{~B} 36 * \mathrm{~B} 23) /(\mathrm{B} 32 * \mathrm{~B} 37) * \mathrm{~B} 41^{\wedge} 2$ \\
\hline 44 & $\mathrm{r}_{\mathrm{B}}^{2}\left[\mathrm{~mm}^{2}\right]$ & $=\mathrm{B} 31^{\wedge} 2+\mathrm{B} 32^{\wedge} 2-2^{*} \mathrm{~B} 31^{*} \mathrm{~B} 32 * \mathrm{~B} 36$ \\
\hline 45 & $\mathrm{r}_{\mathrm{B}}[\mathrm{mm}]$ & $=\mathrm{SQRT}(\mathrm{B} 44)$ \\
\hline 46 & $\mathrm{r}_{\mathrm{B}}^{\prime}[\mathrm{mm}]$ & $=\mathrm{B} 31 * \mathrm{~B} 32 * \mathrm{~B} 37 * \mathrm{~B} 23 / \mathrm{B} 45$ \\
\hline 47 & $\cos \alpha_{B}$ & $=\left(\mathrm{B} 32^{\wedge} 2+\mathrm{B} 44-\mathrm{B} 31^{\wedge} 2\right) /\left(2^{*} \mathrm{~B} 32^{*} \mathrm{~B} 45\right)$ \\
\hline 48 & $\sin \alpha_{B}$ & $=\mathrm{B} 31 * \mathrm{~B} 37 / \mathrm{B} 45$ \\
\hline 49 & $\alpha_{\mathrm{B}}^{\prime}$ & $=\left(\mathrm{B} 32^{\wedge} 2-\mathrm{B} 31^{\wedge} 2-\mathrm{B} 44\right) /\left(2^{*} \mathrm{~B} 44\right)^{*} \mathrm{~B} 23$ \\
\hline 50 & $\sin \left(\delta+\psi_{2}\right)$ & $=\mathrm{B} 40 * \mathrm{~B} 36+\mathrm{B} 37 * \mathrm{~B} 41$ \\
\hline 51 & $\cos \left(\delta+\psi_{2}\right)$ & $=\mathrm{B} 41 * \mathrm{~B} 36-\mathrm{B} 40 * \mathrm{~B} 37$ \\
\hline 52 & $\cos \mathrm{B}$ & $=\mathrm{B} 50 * \mathrm{~B} 47+\mathrm{B} 48 * \mathrm{~B} 51$ \\
\hline 53 & $\sin B$ & $=\mathrm{B} 50 * \mathrm{~B} 48-\mathrm{B} 51 * \mathrm{~B} 47$ \\
\hline 54 & $\mathrm{r}_{\mathrm{A}}^{2}\left[\mathrm{~mm}^{2}\right]$ & $=\mathrm{B} 44+\mathrm{B} 33^{\wedge} 2-2 * \mathrm{~B} 33^{*} \mathrm{~B} 45^{*} \mathrm{~B} 52$ \\
\hline 55 & $\mathrm{r}_{\mathrm{A}}[\mathrm{mm}]$ & $=\mathrm{SQRT}(\mathrm{B} 54)$ \\
\hline 56 & $\cos \mu$ & $=\left(\mathrm{B} 54+\mathrm{B} 44-\mathrm{B} 33^{\wedge} 2\right) /\left(2^{*} \mathrm{~B} 55^{*} \mathrm{~B} 45\right)$ \\
\hline 57 & $\sin \mu$ & $=\mathrm{B} 33 / \mathrm{B} 55^{*} \mathrm{~B} 53$ \\
\hline 58 & $\mathrm{~B}^{\prime}$ & $=\mathrm{B} 43+\mathrm{B} 23+\mathrm{B} 49$ \\
\hline \multirow[t]{2}{*}{59} & $\mathrm{r}_{\mathrm{A}}^{\prime}[\mathrm{mm}]$ & $=(\mathrm{B} 45 * \mathrm{~B} 46-\mathrm{B} 33 * \mathrm{~B} 46 * \mathrm{~B} 52$ \\
\hline & & $+\mathrm{B} 33 * \mathrm{~B} 45 * \mathrm{~B} 53 * \mathrm{~B} 58) / \mathrm{B} 55$ \\
\hline 60 & $\mu^{\prime}$ & $=\mathrm{B} 33 /(\mathrm{B} 55 * \mathrm{~B} 56) *(\mathrm{~B} 52 * \mathrm{~B} 58-\mathrm{B} 53 * \mathrm{~B} 59 / \mathrm{B} 55)$ \\
\hline 61 & $\alpha_{A}^{\prime}$ & $=\mathrm{B} 49+\mathrm{B} 60$ \\
\hline 62 & $\cos \alpha_{\mathrm{A}}$ & $=\mathrm{B} 47 * \mathrm{~B} 56-\mathrm{B} 48 * \mathrm{~B} 57$ \\
\hline 63 & $\sin \alpha_{\mathrm{A}}$ & $=\mathrm{B} 48 * \mathrm{~B} 56+\mathrm{B} 57 * \mathrm{~B} 47$ \\
\hline 64 & $\cos \alpha$ & $=\mathrm{B} 50 * \mathrm{~B} 63-\mathrm{B} 51 * \mathrm{~B} 62$ \\
\hline 65 & $\theta_{\mathrm{A}}^{\prime}$ & $=1+\mathrm{B} 61$ \\
\hline \multirow[t]{2}{*}{66} & $\cos \alpha_{0}$ & $=\left((\mathrm{B} 6+\mathrm{B} 33)^{\wedge} 2+\mathrm{B} 32^{\wedge} 2-\mathrm{B} 31^{\wedge} 2\right)$ \\
\hline & & $/(2 *(\mathrm{~B} 6+\mathrm{B} 33) * \mathrm{~B} 32)$ \\
\hline 67 & $\sin \alpha_{0}$ & $=\mathrm{B} 31 * \operatorname{SIN}(\mathrm{B} 34) /(\mathrm{B} 6+\mathrm{B} 33)$ \\
\hline 68 & $\cos \gamma$ & $=\mathrm{B} 62 * \mathrm{~B} 66+\mathrm{B} 63 * \mathrm{~B} 67$ \\
\hline 69 & $\sin \gamma$ & $=\mathrm{B} 63 * \mathrm{~B} 66-\mathrm{B} 67 * \mathrm{~B} 62$ \\
\hline 70 & $\cos \theta_{\mathrm{A}}$ & $=\mathrm{B} 73 * \mathrm{~B} 68-\mathrm{B} 74 * \mathrm{~B} 69$ \\
\hline 71 & $\sin \theta_{\mathrm{A}}$ & $=\mathrm{B} 74 * \mathrm{~B} 68+\mathrm{B} 69 * \mathrm{~B} 73$ \\
\hline 72 & $\varphi[\mathrm{rad}]$ & $=\mathrm{B} 15 * \mathrm{~B} 2$ \\
\hline 73 & $\cos \varphi$ & $=\operatorname{COS}(\mathrm{B} 72)$ \\
\hline 74 & $\sin \varphi$ & $=\operatorname{SIN}(B 72)$ \\
\hline 76 & Trasare profil & \\
\hline 77 & $\mathrm{x}_{\mathrm{C}}[\mathrm{mm}]$ & $=\mathrm{B} 55^{*} \mathrm{~B} 70$ \\
\hline 78 & $\mathrm{y}_{\mathrm{C}}[\mathrm{mm}]$ & $=\mathrm{B} 55 * \mathrm{~B} 71$ \\
\hline 80 & $\cos \alpha$ & $=\mathrm{B} 23 * \mathrm{~B} 31 * \mathrm{~B} 41 / \mathrm{B} 55$ \\
\hline 81 & $\cos \alpha \cos \delta$ & $=\mathrm{B} 80 * \mathrm{~B} 41$ \\
\hline 82 & $\mathrm{D}$ & $=\mathrm{B} 65^{*} \mathrm{~B} 41^{\wedge} 2$ \\
\hline 83 & $\eta_{\mathrm{i}}$ & $=\mathrm{B} 81^{\wedge} 2$ \\
\hline \multirow[t]{6}{*}{86} & $\Delta x(0)[\mathrm{mm}]$ & $=(1)^{*}\left(\left(\mathrm{~B} 33^{\wedge} 2+2 * \mathrm{~B} 3 * \mathrm{~B} 30\right) *\left(\mathrm{~B} 22^{*} * \mathrm{~B} 31 / \mathrm{B} 28\right)^{\wedge} 2\right.$ \\
\hline & & $+2 * \mathrm{~B} 3 * \mathrm{~B} 7 *(\mathrm{~B} 30+\mathrm{B} 3) *(\mathrm{~B} 22 * \mathrm{~B} 31 / \mathrm{B} 28)$ \\
\hline & & $+\left(\mathrm{B} 30^{\wedge} 2 /(\mathrm{B} 30+\mathrm{B} 3)^{*} \mathrm{~B} 10+(\mathrm{B} 30+\mathrm{B} 3)^{*} \mathrm{~B} 11\right)$ \\
\hline & & $\left.{ }^{*} \mathrm{~B} 13 * 0,001 *(\mathrm{~B} 115 * \mathrm{~B} 23 * \mathrm{~B} 31 / \mathrm{B} 28)^{\wedge} 2\right)$ \\
\hline & & $/(2 *((\mathrm{~B} 22 * \mathrm{~B} 31 / \mathrm{B} 28)+\mathrm{B} 3 * \mathrm{~B} 7 /(\mathrm{B} 30+\mathrm{B} 3))$ \\
\hline & & $\left.*(\mathrm{~B} 30+\mathrm{B} 3)^{\wedge} 2\right)$ \\
\hline \multirow[t]{4}{*}{87} & $\Delta \mathrm{x}[\mathrm{mm}]$ & $=(1)^{*}\left(\left(\mathrm{~B} 3{ }^{\wedge} 2+2 * \mathrm{~B} 3 * \mathrm{~B} 30\right) *\left(\mathrm{~B} 22^{*} * \mathrm{~B} 31 / \mathrm{B} 28\right)^{\wedge} 2\right.$ \\
\hline & & $+2 * \mathrm{~B} 3 * \mathrm{~B} 7 *(\mathrm{~B} 30+\mathrm{B} 3) *(\mathrm{~B} 22 * \mathrm{~B} 31 / \mathrm{B} 28)$ \\
\hline & & $+\left(\mathrm{B} 30^{\wedge} 2 /(\mathrm{B} 30+\mathrm{B} 3)^{*} \mathrm{~B} 10+(\mathrm{B} 30+\mathrm{B} 3)^{*} \mathrm{~B} 11\right)$ \\
\hline & & $\left.{ }^{*} \mathrm{~B} 141 * 0,001 *\left(\mathrm{~B} 115^{*} \mathrm{~B} 23 * \mathrm{~B} 31 / \mathrm{B} 28\right)^{\wedge} 2\right)$ \\
\hline
\end{tabular}




\begin{tabular}{|c|c|c|}
\hline & & $\begin{array}{l}/(2 *((\mathrm{~B} 22 * \mathrm{~B} 31 / \mathrm{B} 28)+\mathrm{B} 3 * \mathrm{~B} 7 /(\mathrm{B} 30+\mathrm{B} 3)) \\
\left.*(\mathrm{~B} 30+\mathrm{B} 3)^{\wedge} 2\right)\end{array}$ \\
\hline 91 & $\mathrm{x}[\mathrm{mm}]$ precis & $=\mathrm{B} 22 * \mathrm{~B} 31 / \mathrm{B} 28+\mathrm{B} 87$ \\
\hline 92 & $\Delta \varphi[\mathrm{rad}]$ & $=\mathrm{B} 14 * \mathrm{~B} 2$ \\
\hline 93 & $\mathrm{G}$ & $=1 / \mathrm{B} 92^{\wedge} 2$ \\
\hline 94 & $\mathrm{x}^{\prime \prime}[\mathrm{mm}]$ & $=\mathrm{B} 93 *(\mathrm{C} 91+\mathrm{AO} 91-2 * \mathrm{~B} 91)$ \\
\hline 95 & $\mathrm{H}$ & $=1 /(2 * \mathrm{~B} 92)$ \\
\hline 96 & $\mathrm{x}^{\prime}[\mathrm{mm}]$ & $=\mathrm{B} 95 *(\mathrm{C} 91-\mathrm{AO} 91)$ \\
\hline 97 & $\mathrm{a}\left[\mathrm{m} / \mathrm{s}^{2}\right]$ & $=\mathrm{B} 94 * \mathrm{~B} 141 * 0,001$ \\
\hline 98 & $\mathrm{v}[\mathrm{m} / \mathrm{s}]$ & \\
\hline 99 & $\mathrm{~s} *[$ verificare $]$ & $=\mathrm{B} 3 *(\mathrm{~B} 7+\mathrm{B} 8) / \mathrm{B} 9$ \\
\hline 100 & $\mathrm{cb}[]$ & $=2,2$ \\
\hline 101 & $\mathrm{~b}_{\text {cama }}[\mathrm{mm}]$ & $=10$ \\
\hline 102 & $\rho_{\text {cama }}\left[\mathrm{g} / \mathrm{cm}^{3}\right]$ & $=9$ \\
\hline 103 & $\mathrm{~m}_{\mathrm{c}} / 2[\mathrm{~kg}]$ & $\begin{array}{l}=\mathrm{B} 101 / 2 *(\mathrm{~B} 6 \wedge 2 * \mathrm{PI}()+\mathrm{B} 6 * \mathrm{~B} 28 * \mathrm{~B} 8 * \\
\operatorname{SIN}(\mathrm{B} 2)) * \mathrm{~B} 102 * 10^{\wedge}(-6)\end{array}$ \\
\hline 104 & $\mathrm{~m}_{\mathrm{S}}[\mathrm{kg}]$ supapa & $=0,0532$ \\
\hline 105 & $\mathrm{~m}_{\mathrm{TS}}[\mathrm{kg}]$ talersupapa & $=0,0185$ \\
\hline 106 & $\mathrm{~m}_{\mathrm{AS}}[\mathrm{kg}] \operatorname{arcsupapa}$ & $=0,0332$ \\
\hline 107 & $\mathrm{~m}_{\mathrm{cu}}[\mathrm{kg}]$ culbutor & $=0,052$ \\
\hline 108 & $\mathrm{~m}_{\mathrm{T}}[\mathrm{kg}]$ tachet & $=0,0353$ \\
\hline 109 & $\mathrm{~m}_{\mathrm{t}}[\mathrm{kg}] \mathrm{tija}$ & $=0,0322$ \\
\hline 110 & $\mathrm{~K}_{\text {Cama }}[\mathrm{N} / \mathrm{mm}]$ & $=163960$ \\
\hline 111 & $\mathrm{~K}_{\text {Tachet }}[\mathrm{N} / \mathrm{mm}]$ & $=15000000$ \\
\hline 112 & $\mathrm{~K}_{\mathrm{tija}}[\mathrm{N} / \mathrm{mm}]$ & $=23820$ \\
\hline 113 & $\mathrm{~K}_{\text {culbutor }}[\mathrm{N} / \mathrm{mm}]$ & $=5044$ \\
\hline 114 & $\mathrm{~K}_{\text {Supapa }}[\mathrm{N} / \mathrm{mm}]$ & $=600000$ \\
\hline 115 & $\mathrm{D}[\mathrm{l}$ & $=\mathrm{B} 65^{*} \mathrm{~B} 41^{\wedge} 2$ \\
\hline 120 & le $\left[\mathrm{kg} \cdot \mathrm{mm}^{2}\right]$ & $=\mathrm{B} 103 * \mathrm{~B} 55^{*} \mathrm{~B} 59+\mathrm{B} 9 *(\mathrm{~B} 31 / \mathrm{B} 28)^{\wedge} 2 * \mathrm{~B} 23 * \mathrm{~B} 24$ \\
\hline 121 & $\mathrm{I}^{*}\left[\mathrm{~kg} \cdot \mathrm{mm}^{2}\right]$ & $=\mathrm{B} 103 * \mathrm{~B} 54+\mathrm{B} 9 *(\mathrm{~B} 31 / \mathrm{B} 28)^{\wedge} 2^{*} \mathrm{~B} 23^{\wedge} 2$ \\
\hline 123 & $\varphi[\mathrm{rad}]$ & $=\mathrm{B} 2 * \mathrm{~B} 15$ \\
\hline 124 & $\mathrm{~W}_{\mathrm{D}}\left[\mathrm{s}^{-1}\right]$ & $=\mathrm{B} 140$ \\
\hline 126 & $\mathrm{X}(0)[\mathrm{mm}]$ & $=\mathrm{B} 22 * \mathrm{~B} 31 / \mathrm{B} 28+\mathrm{B} 86$ \\
\hline 127 & $\Delta \varphi[\mathrm{rad}]$ & $=\mathrm{B} 14 * \mathrm{~B} 2$ \\
\hline 128 & G & $=1 / \mathrm{B} 127^{\wedge} 2$ \\
\hline 129 & $\mathrm{X}^{\prime \prime}(0)[\mathrm{mm}]$ & $=\mathrm{B} 128 *(\mathrm{C} 126+\mathrm{AO} 126-2 * \mathrm{~B} 126)$ \\
\hline 130 & $\mathrm{H}$ & $=1 /(2 * \mathrm{~B} 127)$ \\
\hline 131 & $\mathrm{X}^{\prime}(0)[\mathrm{mm}]$ & $=\mathrm{B} 130 *(\mathrm{C} 126-\mathrm{AO} 126)$ \\
\hline 132 & $\mathrm{a}\left[\mathrm{m} / \mathrm{s}^{2}\right]$ & $=(\mathrm{B} 131 * \mathrm{~B} 117+\mathrm{B} 129 * \mathrm{~B} 115) * \mathrm{~B} 13 * 0,001$ \\
\hline 133 & $\mathrm{v}[\mathrm{m} / \mathrm{s}]$ & $=\mathrm{B} 131 * 0,001 * \mathrm{SQRT}(\mathrm{B} 116)$ \\
\hline 135 & $\mathrm{Mm} * 10^{6}[\mathrm{Nm}]$ & $=\mathrm{B} 30 *(\mathrm{~B} 22 * \mathrm{~B} 31 / \mathrm{B} 28-\mathrm{B} 126) * \mathrm{~B} 131 * 1000$ \\
\hline 136 & Mrez* $10^{6}[\mathrm{Nm}]$ & $=\mathrm{B} 3 *(\mathrm{~B} 7+\mathrm{B} 126) * \mathrm{~B} 131 * 1000$ \\
\hline 137 & $\mathrm{M}^{*} 10^{6}[\mathrm{Nm}]$ & $=\mathrm{B} 135-\mathrm{B} 136$ \\
\hline 138 & $\Delta\left[\mathrm{s}^{-2}\right]$ & $\begin{array}{l}=\mathrm{B} 13 / 4+\mathrm{B} 120 * \mathrm{~B} 137 / \mathrm{B} 121^{\wedge} 2 *(\mathrm{~B} 2 * \mathrm{~B} 14)^{\wedge} 2 \\
+\mathrm{B} 137 / \mathrm{B} 121 *(\mathrm{~B} 2 * \mathrm{~B} 14)\end{array}$ \\
\hline 139 & $\mathrm{dw}\left[\mathrm{s}^{-1}\right]$ & $\begin{array}{l}=(-\mathrm{B} 120 / \mathrm{B} 121 * \mathrm{~B} 2 * \mathrm{~B} 14 * \mathrm{~B} 12-\mathrm{B} 12 / 2+(\mathrm{IF}(\mathrm{B} 138 \\
\left.<0 ; 0 ; \mathrm{B} 138))^{\wedge} 0,5\right) /(\mathrm{B} 120 / \mathrm{B} 121 * \mathrm{~B} 2 * \mathrm{~B} 14+1)\end{array}$ \\
\hline 140 & $\mathrm{~W}_{\mathrm{D}}\left[\mathrm{s}^{-1}\right]$ & $=\mathrm{B} 12+\mathrm{B} 139$ \\
\hline 141 & $\mathrm{~W}_{\mathrm{D}}^{2}\left[\mathrm{~s}^{-2}\right]$ & $=\mathrm{B} 140^{\wedge} 2$ \\
\hline
\end{tabular}

